\title{
Perbandingan Zink Organik dengan Anorganik dan Campuran dengan Mikromineral Lain terhadap Produk Fermentasi dan Kecemaan Pakan In Vitro
}

\section{(Comparison of Organic and Inorganic Zinc, and lts Mixture with Other Microminerals on Affecting In Vitro Rumen Fementation and Feed Digestibility)}

\author{
Wina E, Susana IWR, Tangendjaja B \\ Balai Penelitian Ternak \\ PO Box 221, Bogor 16002 \\ winabudi@yahoo.com
}

\begin{abstract}
The experiment aimed to prepare organic micro minerals ( $\mathrm{Zn}, \mathrm{Mn}, \mathrm{Cu}$ ) methionine, to study their solubility,effect on affecting fermentation products and true feed digestibility in the in vitro rumen fermentation. After preparation of micromineral organics, the products were tested in in vitro rumen fermentation with 4 treatments ie: T1) control (complete feed = P, without Zinc addition), T2) P + organic Zn (Znmet), T3) P+ inorganic Zn (ZnSO4), T4) P+ organic $\mathrm{Zn}+\mathrm{Mn}+\mathrm{Cu}(\mathrm{Zn}+\mathrm{Mn}+\mathrm{Cu}$ met). This in vitro experiment was repeated 4 times and each treatment was done in two fermentation tubes. Total gas, methane, ammonia production and feed digestibility were measured. Organic micro minerals had low solubility during rumen fermentation. Total gas production was increased by organic Zinc addition and was higher than control and inorganic Zinc addition. Ratio methane to total gas production and ammonia production were not significantly different among treatments. True dry matter (TDMD) and organic matter digestibilities (TOMD) were similar between control and organic Zinc addition, however, both TDMD and TOMD of zinc organic and control were higher than those of mineral mixture additions. In conclusion, in the preparation of the organic micromineral, concentration of mineral and methionine $(1 ; 2)$ and $\mathrm{pH} 7$ should be used to get a higher yield. Organic minerals, especially organic zinc, are only slightly dissolved during fermentation in the rumen. Organic zinc compared to inorganic zinc or its mixture with other minerals has an effect on higher total gas in rumen fermentation. In vivo trial in ruminant is warranted to observe the beneficial effect of micro mineral organic on ruminant productivity.
\end{abstract}

Key words: Organic mineral, zinc, total gas, in vitro fermentation

\section{ABSTRAK}

Percobaan ini bertujuan untuk mempersiapkan mineral mikro organik ( $\mathrm{Zn}, \mathrm{Mn}, \mathrm{Cu}$ ) metionin, mempelajari kelarutan dan pengaruhnya terhadap produk fermentasi serta kecernaan pakan sejati dalam fermentasi rumen in vitro. Setelah pembuatan mikromineral organik, produk yang diperoleh diuji pengaruhnya dalam fermentasi rumen in vitro dengan 4 perlakuan yaitu: T1) kontrol (pakan lengkap = P, tanpa penambahan Zink), T2) P + Zn organik (Znmet), T3) P + anorganik Zn ( ZnSO4), T4) P + Zn + Mn + Cu organik ( $\mathrm{Zn}+\mathrm{Mn}+\mathrm{Cu}$ metionin). Eksperimen in vitro ini diulangi 4 kali dan setiap perlakuan dilakukan dalam dua tabung fermentasi. Total gas, metana, produksi amonia dan kecernaan pakan dalam rumen diukur. Mineral mikro organik memiliki kelarutan yang rendah selama fermentasi rumen. Total produksi gas meningkat dengan penambahan Zn organik dan lebih tinggi dari kontrol dan penambahan $\mathrm{Zn}$ anorganik. Rasio metana terhadap total produksi gas dan produksi amonia 
tidak berbeda secara signifikan antar perlakuan. Kecernaan bahan kering "true” (TDBK) dan kecernaan bahan organik (TDBO) sama antara kontrol dan penambahan Zn organik, namun baik TDBK dan TDBO Zn organik dan kontrol lebih tinggi daripada penambahan campuran mineral. Kesimpulannya, dalam teknologi pembuatan mineral mikroorganik, konsentrasi mineral dan metionin (1:2) pH 7 digunakan untuk mendapatkan rendeman yang lebih tinggi. Mineral organik terutama Zn organik hanya sedikit terlarut selama fermentasi di dalam rumen. $\mathrm{Zn}$ organik dibandingkan dengan $\mathrm{Zn}$ anorganik atau campurannya dengan mineral lain memberikan efek terhadap total gas yang lebih tinggi dalam fermentasi rumen. Percobaan suplementasi mineral mikro organik pada ruminansia sangat diharapkan untuk melihat efek yang positif terhadap produktivitas ternak.

Kata kunci: Mineral organik, Zn, total gas, fermentasi in vitro

\section{PENDAHULUAN}

Beberapa mineral mikro diantaranya Zinc (Zn), Mangan (Mn), Tembaga (Cu) dan Cobalt (Co) memiliki peran penting dalam meningkatkan kecernaan serat, performans reproduksi dan kesehatan ternak (Supriyati 2013). Mineral Zn penting untuk mempertahankan kesehatan jaringan kelenjar susu dan jaringan epitel karena Zn mempunyai peran dalam pembelahan sel dan protein sintesis. Zink yang diberikan kepada ternak dilaporkan lebih efisien bila dalam bentuk organik dibandingkan dengan Zn dalam bentuk inorganik. Bila bentuk kompleks dibuat antara mineral dengan asam amino (metionin) maka akan memberikan efek ganda yaitu sebagai sumber mineral mikro dan sumber asam amino yang dibutuhkan untuk produksi susu. Bentuk organik dalam bentuk terikat dengan asam amino yaitu Zink-metionin yang diberikan kepada sapi perah meningkatkan produksi susu secara signifikan (31,8 vs 30,5 kg/hari) dibandingkan dengan ternak kontrol. Selain itu dilaporkan juga bahwa somatic cell count (SCC; 1000/ml) berkurang dari 294 menjadi 196 (kontrol) (Kellog et al. 2004). Dibandingkan dengan mineral anorganik, penambahan mineral mikro ( $\mathrm{Zn}, \mathrm{Mn}, \mathrm{Cu}$ dan $\mathrm{Co}$ ) dalam bentuk organik dapat meningkatkan produksi susu pada periode tengah laktasi (Hackbart et al. 2010). Oleh sebab itu, penelitian ini bertujuan mendapatkan teknologi pembuatan mineral mikro organik dan mengevaluasi pengaruhnya dibandingkan dengan mineral mikro anorganik dan campurannya terhadap produk fermentasi dan kecernaan pakan secara in vitro dengan menggunakan cairan rumen sapi perah.

\section{MATERI DAN METODE}

\section{Pembuatan mineral organik}

Mineral (Zn atau $\mathrm{Mn}, \mathrm{Cu}$ ) sulfat dilarutkan dalam air dan dipanaskan. Lalu ditambahkan metionin. Campuran larutan diaduk dan dipanaskan. Lalu dibuat tanpa dan dengan pengaturan $\mathrm{pH}$. Larutan kemudian disentrifus untuk memisahkan endapan dan supernatan. Supernatan dipisahkan dan dianalisis kandungan mineral terlarut. Endapan dikeringkan di dalam oven dan ditimbang hasil rendemannya serta dianalisis kandungan mineralnya. Masing-masing diulang 2 kali.

\section{Uji kelarutan dari mineral organik dalam larutan rumen buffer}

Mineral organik yang sudah kering masing-masing diinkubasikan dalam buffer rumen selama $0,12,24$ jam pada suhu $39^{\circ} \mathrm{C}$, dilakukan dalam 3 tabung. Subsampel 
larutan diambil lalu disentrifus pada kecepatan 3000 rpm selama 15 menit dan diambil supernatannya. Kemudian dianalisis kandungan mineral mikro dalam supernatan menggunakan AAS sehingga dapat dihitung berapa kandungan mineral yang terlarut ke dalam buffer rumen selama inkubasi.

\section{Uji in vitro mineral organik terhadap produk fermentasi dan nilai kecernaan pakan sapi perah}

Sebanyak 0,75 gram sampel pakan yang diberi 4 perlakuan yaitu: T1) kontrol (pakan lengkap $=\mathrm{P}$, tanpa penambahan Zinc), T2) $\mathrm{P}+$ Zn organik (Znmet, Zn 50ppm), T3) P + anorganik Zn ( ZnSO4, Zn 50ppm), T4) P + Zn + Mn + Cu organik (Zn + Mn + Cu metionin, Zn 50ppm, Mn ) dimasukkan ke dalam botol yang berisi $75 \mathrm{ml}$ buffer cairan rumen sapi dan diinkubasi selama 48 jam sambil diukur total gas dan gas metana pada jam inkubasi 0, 3, 6, 12, 24 dan 48 jam. Pakan yang digunakan merupakan campuran rumput, konsentrat dan ampas tahu (48:47:5\%). Sisa pakan disaring dan langsung dimasak dengan larutan Netral Detergent Solution. Sedangkan supernatan dianalisis untuk kadar amonia. Residu dikeringkan dan kemudian nilai "true” kecernaan BK dapat dihitung. Setelah residu diabukan, maka dapat dihitung nilai "true" kecernaan BO. Eksperimen in vitro ini diulangi 4 kali dalam waktu yang berbeda dan setiap perlakuan dilakukan dalam dua tabung fermentasi. Percobaan ini dirancang dalam rancangan acak kelompok. Kelompok adalah kegiatan in vitro yang dilakukan pada waktu yang berbeda.

\section{HASIL DAN PEMBAHASAN}

Teknologi pembuatan mineral mikro organik dilakukan berdasarkan metode yang ada. Pada awal penelitian dilakukan pembuatan mineral mikro organik antara mineral mikro dengan metionin dilakukan tanpa mengatur $\mathrm{pH}$ larutan dan dapat dilihat dari Tabel 2. Reaksi antara mineral dan metionin dengan proporsi 1:1 molar menghasilkan rendeman yang rendah; hanya mencapai 73,12\% dari hasil rendeman yang diharapkan. Sedangkan bila proporsi mineral dan metionin diubah menjadi 1:2 molar, maka hasil rendeman yang diperoleh lebih tinggi. Begitu pula pada reaksi dengan proporsi 1:1 molar dihasilkan mineral mikro organik dengan konsentrasi mineral yang rendah. Hal ini mungkin disebabkan oleh rendahnya $\mathrm{pH}$ larutan ketika larutan mineral direaksikan dengan larutan metionin.

Tabel 2. Rendeman dan kandungan mineral dalam produk mineral mikro organik

\begin{tabular}{llll}
\hline \hline $\begin{array}{l}\text { Mineral mikro } \\
\text { organik }\end{array}$ & Perlakuan & Rendeman (\%) & $\begin{array}{l}\text { \% Mineral } \\
\text { dalam produk }\end{array}$ \\
\hline Znmet & min:met (1:1), tanpa pH & $52,75 \pm 6,63$ & $4,30 \pm 0,82$ \\
Mnmet & min:met (1:1), tanpa pH & $73,12 \pm 7,48$ & $3,61 \pm 0,36$ \\
Cumet & min:met (1:1), tanpa pH & $68,51 \pm 3,39$ & $10,26 \pm 1,12$ \\
Zn (met) & min:met (1:2), dengan pH & $73,89 \pm 1,72$ & $10,86^{*}$ \\
Mn (met) & min:met (1:2), dengan pH & $75,79 \pm 1,56$ & $16,58^{*}$ \\
Cu (met) & min:met (1:2), dengan pH & $93,48 \pm 2,50$ & $14,32^{*}$ \\
\hline
\end{tabular}

* analisis tunggal 
Dilaporkan bahwa kelarutan komplek mineral metionin semakin tinggi dengan semakin rendahnya $\mathrm{pH}$ larutan (de Souza et al. 2007). Ketika pH larutan dinaikkan maka terlihat endapan mineral komplek yang terbentuk lebih banyak dan konsentrasi mineral yang lebih tinggi (Tabel 2). Molekul metionin berikatan dengan kation Zn melalui atom Oksigen dari grup karboksilat dan melalui atom nitrogen dari grup amine menghasilkan cincin khelat 5 atom (de Souza et al. 2007).

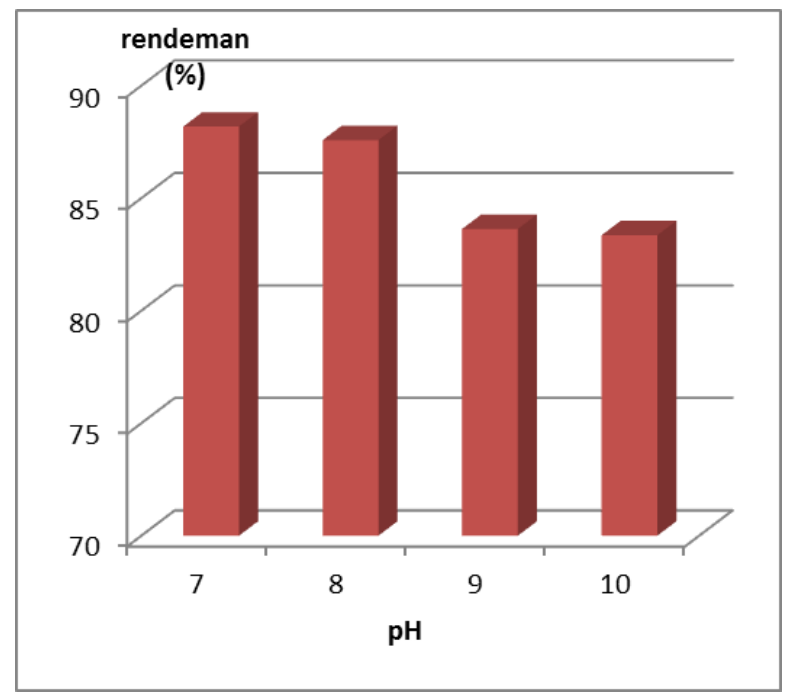

Gambar 1. Pengaruh pH larutan terhadap persentase hasil rendeman Zn metionin

Gambar 1 memperlihatkan bahwa semakin tinggi pH larutan pada pembentukan Zn metionin menyebabkan semakin rendah rendeman yang diperoleh. Hal ini berlainan dengan yang dilaporkan oleh de Souza et al. (2007) yang mendapatkan rendeman pada $\mathrm{pH}$ rendah sebesar 64\% dan meningkat pada $\mathrm{pH}$ tinggi sebesar 92\%. Pada $\mathrm{pH}$ larutan di bawah 7, senyawa komplek yang terbentuk adalah Zn metionin dengan perbandingan 1:1 mol sedangkan pada $\mathrm{pH}$ yang semakin tinggi senyawa yang terbentuk adalah $\mathrm{Zn}$ metionin (1:2 mol). Senyawa Zn metionin (1:2 mol) disebut senyawa khelat dengan ikatan kovalen kordinat yang membuat senyawa ini lebih stabil di dalam rumen dibandingkan senyawa anorganik.

Tabel 3. Kelarutan mineral mikro dalam buffer rumen selama fermentasi rumen in vitro

\begin{tabular}{llccc}
\hline \hline \multirow{2}{*}{ Jenis mineral } & \multirow{2}{*}{$\begin{array}{l}\text { Mineral } \\
\text { awal }(\mu \mathrm{g})\end{array}$} & 0 jam & 12 jam & 24 jam \\
\cline { 3 - 5 } & 10860 & $6,0 \pm 6,0$ & 0 & 0 \\
Zn organik & 15680 & $116,3 \pm 105,0$ & $105,0 \pm 9,4$ & $37,3 \pm 3,5$ \\
Mn organik & 4296 & $1057,5 \pm 315,0$ & $37,5 \pm 26,7$ & $130,8 \pm 50,4$ \\
Cu organik & & &
\end{tabular}

Ketika produk Zn organik ditambahkan dalam jumlah yang tertentu dan difermentasi secara in vitro bertujuan untuk melihat kelarutannya dalam waktu tertentu. Terlihat bahwa Zn metionin memiliki kandungan Zn yang tinggi pada awal sebelum diinkubasi tetapi kandungan Zn sangat kecil atau tidak terdeteksi di dalam larutan fermentasi sampai 
24 jam inkubasi. Hal ini menunjukkan bahwa Zn organik sebagai metionin cukup stabil di dalam rumen. Kestabilan Zincmet jauh lebih tinggi dibandingkan dengan Mnmet dan Cumet sehingga diharapkan Zincmet hanya sedikit terdegradasi di dalam rumen dan baru di pascarumen, Zn dan metionin yang terpecah seluruhnya bermanfaat untuk ternaknya.

Ketika produk Zn organik yang mengandung 50 ppm Zn ke dalam pakan dan difermentasi secara in vitro, maka produksi total gas hasil fermentasi meningkat jauh lebih tinggi dari pada kontrol (tanpa mineral) dan lebih tinggi bila dibandingkan dengan perlakuan penambahan Zn anorganik atau campuran mineral organik (Tabel 4). Tidak ada perbedaan antara produksi total gas antara penambahan Zn anorganik dengan mineral campuran. Hal ini menunjukkan bahwa Zn-organik berfungsi lebih baik karena senyawa organik yang digunakan adalah senyawa metionin yang juga dapat bermanfaat bagi ternak.

Nilai total gas dan gas metana yang diproduksi dan rasionya serta produksi amonia selama fermentasi in vitro ditampilkan pada Tabel 4. Total gas yang diproduksi selama 48 jam fermentasi secara signifikan $(\mathrm{P}<0,05)$ lebih tinggi pada penambahan Zn organik dibandingkan dengan mineral anorganik. Walaupun meningkat produksi gas in vitro seperti yang dilaporkan oleh Mallaki et al. (2015), peningkatan tersebut tidak berbeda nyata antara Zn organik dengan Zn anorganik pada dosis 20ppm, tetapi nilai asimptotik (b) nyata lebih tinggi pada Zn organik dibandingkan Zn anorganik.

Tabel 4. Produksi gas total, metana, rasio metana/total gas dan amonia hasil fermentasi in vitro yang ditambah mineral mikro

\begin{tabular}{lcccc}
\hline \hline & $\begin{array}{c}\text { Total gas } \\
(\mathrm{ml} / \mathrm{gBK})\end{array}$ & $\begin{array}{c}\text { Metana } \\
(\mathrm{ml} / \mathrm{g} \mathrm{BK})\end{array}$ & $\begin{array}{c}\text { Rasio } \\
\text { metana/total gas } \\
(\mathrm{M} / \mathrm{TG})\end{array}$ & $\begin{array}{c}\text { Amonia } \\
(\mathrm{mmol} / \mathrm{g} \text { BK })\end{array}$ \\
\hline Kontrol & $164,80^{\mathrm{b}}$ & 34,21 & 0,21 & 26,51 \\
Zn org. & $190,72^{\mathrm{a}}$ & 39,55 & 0,21 & 34,14 \\
Zn anorg. & $168,76^{\mathrm{b}}$ & 31,16 & 0,19 & 30,34 \\
Zn, Mn, Cu org. & $168,66^{\mathrm{b}}$ & 35,01 & 0,21 & 35,67 \\
sem & 5,63 & 2,00 & 0,01 & 2,66 \\
$\mathrm{P}$ & 0,02 & 0,08 & 0,27 & 0,10 \\
\hline
\end{tabular}

${ }^{\text {ab }}$ dalam satu kolom menunjukkan perbedaan nyata $(\mathrm{P}<0,05)$

Walaupun produksi gas metana lebih tinggi pada penambahan Zink organik, nilai rasio metana/total gas (Tabel 4) pada penambahan Zn organik sama dengan nilai rasio pada perlakuan kontrol atau penambahan campuran mineral organik. Informasi mengenai pengaruh Zn organik maupun campurannya terhadap metana sangat terbatas.

Produksi amonia cenderung lebih tinggi pada penambahan $\mathrm{Zn}$ organik atau campurannya. Hal ini menunjukkan kemungkinan adanya metionin yang masih dalam bentuk bebas atau tidak terikat dengan Zinc dan metionin ini dapat didegradasi oleh mikroba rumen menjadi amonia. Produksi amonia tergantung dari level Zn organik yang ditambahkan ke dalam fermentasi rumen in vitro. Pada level 20 ppm, produksi amonia tidak berbeda nyata dengan kontrol (Wang et al. 2013), tetapi penambahan Zn anorganik pada level tinggi (330 ppm) menyebabkan pengaruh negatif terhadap produksi amonia (Mousa 2014) karena Zn pada level tinggi mungkin sudah menyebabkan toksik pada mikroba rumen. 
Produksi total gas yang diperoleh lebih tinggi pada penambahan Zn organik menunjukkan adanya fermentasi yang lebih aktif dibandingkan dengan $\mathrm{Zn}$ anorganik. Penambahan $\mathrm{Zn}$ anorganik dan campuran mineral organik memberikan pengaruh negatif terhadap nilai kecernaan bahan kering dan bahan organik sedangkan Zn organik tidak berbeda nyata dengan kontrol (Tabel 5). Dilaporkan sebelumnya oleh Supriyati et al. (2000) bahwa mineral Zn baik yang inorganik maupun organik dapat meningkatkan kecernaan bahan kering. Perbedaan yang terjadi mungkin disebabkan oleh level mineral organik yang ditambahkan ke dalam pakan. Dalam percobaan ini, jumlah Zn yang ditambahkan sebanyak 10 kali lebih banyak (50ppm) dari yang dilaporkan oleh Supriyati et al. (2000). Wang et al. (2013) melaporkan bahwa dengan meningkatnya level penggunaan dari $10 \mathrm{ppm}$ menjadi $20 \mathrm{ppm}$ maka nilai kecernaan BK mulai menurun. Faktor lain adalah bentuk Zn organik atau cara pembuatan Zn organik yang berbeda. Dalam penelitian ini digunakan Zn metionin sedangkan Zn proteinat dalam penelitian Supriyati et al. (2000) dan Zinc yang diikat di dalam kapang pada penelitian Tanuwiria et al. (2010). Zn organik dalam bentuk Zn asam amino dan Zn proteinat meningkatkan kecernaan bahan kering dibandingkan Zn sulfat tetapi peningkatan tertinggi pada penggunaan Zn asam amino (Wang et al. 2013).

Pencampuran Zn dengan Cu dan Mn menurunkan nilai kecernaan pakan, dan hal yang serupa dialami oleh Supriyati et al. (2000). Perlu kewaspadaan dalam penambahan atau kombinasi mineral mikro terutama mineral Cu karena dapat bersifat antimikroba bila jumlahnya lebih dari yang dibutuhkan oleh mikroba rumen.

Tabel 5. Nilai kecernaan bahan kering dan bahan organik pakan in vitro yang ditambah mineral mikro

\begin{tabular}{lcc}
\hline \hline & KCBK & KCBO \\
\hline Kontrol & $83,26^{\mathrm{a}}$ & $84,09^{\mathrm{a}}$ \\
Zn organik & $85,55^{\mathrm{a}}$ & $86,32^{\mathrm{a}}$ \\
Zn anorganik & $80,15^{\mathrm{ab}}$ & $81,13^{\mathrm{ab}}$ \\
Zn, Mn, Cu organik & $72,20^{\mathrm{b}}$ & $73,63^{\mathrm{b}}$ \\
sem & $2,96^{\circ}$ & $2,76^{\circ}$ \\
\hline
\end{tabular}

${ }^{\text {ab }}$ dalam satu kolom menunjukkan perbedaan nyata $(\mathrm{P}<0,05)$

\section{KESIMPULAN}

Rendeman yang lebih tinggi diperoleh bila konsentrasi mineral dan metionin (1:2) pada $\mathrm{pH}$ 7. Mineral organik terutama Zn organik hanya sedikit terlarut selama fermentasi di dalam rumen. Zn organik dibandingkan dengan Zn anorganik atau campurannya dengan mineral lain memberikan efek terhadap total gas yang lebih tinggi dalam fermentasi rumen.

\section{DAFTAR PUSTAKA}

de Souza AR, Martins LP, de Faria LC, Martins MEP, Fereira RN, da Silva AML, Gil ES, da Conceicao EC. 2007. Studies on the bioavailability of zinc in rats supplementated with two different Zinc-methionine compounds. Lat Am J Pharm. 26:825-830. 
Hackbart KS, Ferreira RM, Dietsche AA, Socha MT, Shaver RD, Wiltbank MC, Fricke PM. 2010. Effect of dietary organic zinc, manganese, copper, and cobalt supplementation on milk production, follicular growth, embryo quality, and tissue mineral concentrations in dairy cows. J Anim Sci. 88:3856-3870.

Kellogg DW, Tomlinson DJ, Socha MT, Johnson AB. 2004. Effects of Zinc methionine complex on milk production and somatic cell count of dairy cows: Twelve-trial summary. PAS. 20:295-301.

Mallaki M, Norouzian MA, Khadem AA. 2013 Effect of organic zinc supplementation on growth, nutrient utilization, and plasma zinc status in lambs. Turk J Vet Anim Sci. 39:75-80.

Mousa SA. 2014. Influence of in vitro addition of metal ions salts on rumen fermentation parameters and selected ruminal enzymes activity in sheep and goats. Life Sci J. 11:198204.

Supriyati, Yulistiani D, Wina E, Haryanto B. 2000. Pengaruh suplementasi Zn, Cu dan Mo anorganik dan organik terhadap kecemaan rumput secara in vitro. JITV. 5:32-37.

Supriyati. 2013. Seng organik sebagai imbuhan pakan ruminansia. Wartazoa. 23:142-157.

Wang RL, Liang JG, Lu L, Zhang LY, Li SF, Luo XG. 2013. Effect of Zinc source on performance, Zinc status, immune response and rumen fermentation of lactating cows. Biol Trace Elem Res. 152:16-24. 